\title{
Research on the College English Teachers' Developing Direction under the "Internet +" era
}

\author{
ZHENG Weiwei ${ }^{1, a}$ \\ ${ }^{1}$ Jilin Business and Technology College, Changchun City 130507,China \\ azhengweiwei@126.com
}

Keywords: "Internet +" era, college English teacher, sustainable development, developing direction

\begin{abstract}
The new education idea of "internet +" era has brought great opportunities and challenges for college English teachers' professional ability development. The university English teachers should initiatively adapt to the needs of higher education and the social sustainable development, actively explore for their professional ability of sustainable development path, so as to further improve the effect of college English teaching and the teaching quality. With the development of the society, our country demands for more and more foreign language talents and the requirements are also increasing day by day. This requires that English teachers, especially the college English teachers, should have a higher quality and ability. And the development path of the college English teachers' professional in our country is relatively single, cannot satisfy the needs of teachers' professional development. Based on this kind of situation, to promote a variety of English teachers' professional development path has great practical significance.
\end{abstract}

\section{The education theory of "internet + " era}

"Internet +" means " use information and communication technology to integrate the Internet and all walks of life, including traditional industries, in the field of new to create a new ecological based on the platform of the Internet ". In fact, the society did not form a unified understanding of the connotation of the "Internet +", also is difficult to form a consensus with different industry, different crowd stood in their view, which will produce different definitions and interpretations to the "Internet +". To meet "Internet +" from the perspective of education, we should see this trend is not only the innovation of education technology, especially the impact on the learning, teaching, organization pattern and thus bring the profound influence of education concept and system. "Internet + education" makes the Internet deeply integrated with the traditional education mode by using the Internet platform and new information and communication technology and innovate ecological education development. Internet has changed the traditional education mode to a great extent, make it more popular, and can meet the demand of students' personalized learning, but also have a significant impact on the teacher's role, classroom teaching mode and teaching methods, teaching design and evaluation mode and teachers' teaching thought and teaching ability.

"Internet +" era led to a series of changes in the field of education in foreign language teaching, it makes teaching practice facing the new information environment, the new teaching mode of micro lesson, lesson for new mode, turning the classroom teaching booming in recent years are very good examples. Foreign language education outlook, college English teaching, college English teachers' development under "Internet + " era will have new change for higher foreign language education reform and development, has brought the unprecedented vitality and challenges. Based on class, class, turning the classroom "Internet + education" new model not only can the abstract, boring knowledge visualization, visual and vivid embodiment, and can be independent learning anytime and anywhere, breakthrough the limitation of time and space; at the same time, "Internet + education" new model not only can expand the coverage of high quality education resources, promote education fair, improve the efficiency of foreign language education and quality education, but also help teachers to create more innovative, more valuable way of education, realize their aptitude, promote the students learning ability of independent development, etc., these undoubtedly has brought many opportunities for the "Internet +" era the development of education. 


\section{Current situation and problems of teacher professional development}

2.1 Pre-service education is imperfect China's foreign language education has the phenomenon of putting emphasis on subject knowledge and less on subject teaching ability. Most of the cultivation is centered in the normal education subject knowledge, related subjects such as pedagogy, psychology, sociology and science account for very little proportion of the curriculum. The teaching methods and teaching quality of training could not reach the requirements of normal education. University last year a month of practice teaching is the purpose of the students in the teachers' guidance, have a purpose, in a planned way the learned theory knowledge is applied to the teaching practice, the combination of theory and practice, summarize and accumulated certain experience in teaching for the students. Because of conflicts with graduation thesis, one's deceased father grind, and looking for a job, internship effect has the subject knowledge represent only can "teach", doesn't mean "teaching". To achieve the level of "teaching", require the system to the teaching theory and teaching methods and skills training.

2.2 The teaching idea is lag behind The teacher's teaching idea is relatively backward and old. Many teachers are not familiar with the rules of learning a second language, don't understand the development of the theory of psychology and language teaching, to well carry out the communicative teaching in the teaching idea, ignoring the role of students as the main body,

Failed to stimulate students' interest in learning, or create a lot of opportunity for students to participate in class activities or the creation of learning motivation, students' interaction and interactive learning environment, etc. Many teachers follow the role of teaching, teaching the grammar translation method, detailed interpretation of the language knowledge in their native language and translate the text. In class, the teacher is "them", students can only listen to the teacher to teach language knowledge, has no chance to speak with the language of the target language in real practice.

2.3 Scientific research consciousness and ability are weak China's foreign language teaching research level is low, cannot be compared with foreign counterparts, embodied in foreign language teaching theory and practice. The study of foreign language teaching from blindly following foreign trendy theory to favor linguistics research, copying foreign theoretical research results, the result is inconsistent with the actual situation of our country, it is difficult to put into teaching practice. And experienced teachers and other education workers often limited by the boundaries of the individual small, not to their own practical experience through a certain method to theory and promotion, caused the general teachers "from one", the improvement of teaching ability mainly depends on the accumulation of experience. In theory and practice that foreign language teaching research level of the need to strengthen the scientific research ability

2.4 Lack the consciousness of cooperation and development Wallace (1998:207-1998) believes that teachers' professional development isolation for a long time, for the sustainable development of the career is a great hindrance. Professional isolation is not broken; teachers' professional development can't go smoothly. In recent years, many college English teachers have gradually realized the importance of career development, promotion and the development of vocational ability's enthusiasm is very high, and have mastered some effective methods, but the lack of consciousness of cooperation and development, professional development for a long time isolation, the adopted by most of the way a person independently. These teachers preparing to write lesson plans alone for a long time, did not discuss with colleagues and exchange views and opinion on teaching materials and teaching plan, no cooperation or hear each other in class, also do not welcome colleagues to listen - involves fear on their own teaching evaluation. Scientific research subject most of the work done by the principal himself, others just do some supporting work. No chance to attend academic conferences and seminars to and colleague, recent developments in the field of don't know anything about this does not belong to any professional team, unable to hear different opinions, let alone to help each other, sharing resources, make progress together. 


\section{Challenges of teacher professional development under "internet + " era}

"Internet +" era let education transfer from closed to open, and teachers are no longer authority. In "Internet +" era, students can obtain new knowledge or information anytime and anywhere through the computer, mobile phone equipment or online in various forms of exchanges and discussions, the classroom is no longer the only way to acquire knowledge, teachers are no longer the only source of knowledge for students to obtain. Interaction between teachers and students is more diversified, more focused on the guidance of the answer rather than the lectures, teachers will gradually change from the body of the teaching activities into the teaching process of the organizer and guide. Students as the role of cognitive subject will be fully reflected, everyone is not only the knowledge of learners, and at the same time, they can also be a contributor of knowledge. In "Internet +" era, the new education idea will generate disruptive change, college English classroom teaching of college English teachers will face unprecedented challenges. Therefore, how to meet new challenges, to adapt to the era of "Internet +", meet the new requirements for college English classroom teaching, improve their professional ability are worthy of deep thinking and discussion for college English teachers.

In the era of "Internet + education", college English teachers' classroom teaching activities will be a full range of challenges. First of all, with the depth of the integration of Internet and education, college English teachers' traditional teaching concept will be challenged. The traditional teaching model and method have been unable to meet the students' classroom expectations, college English teachers will need to keep pace with The Times, constantly updating the teaching idea, innovating teaching methods, to master new teaching skills. Second, the "Internet +" era of abundant information resources and the quick and efficient way to get information is bound to deconstruct the teacher's knowledge hegemony, flexible way of interaction between teachers and students in classroom teaching is bound to change the way of interaction and the roles between teachers and students in the end, the Internet information age education information network and network data sharp growth, knowledge base and knowledge structure of the college English teachers will inevitably challenged, teaching methods and teaching idea, teacher's role changes will need to have abundant knowledge reserves and reasonable knowledge structure to meet the challenge. In traditional English teaching, college English teachers should have good professional accomplishment, at the same time have simple courseware teaching ability and computer operation flat can be completed. But in the era of "Internet + education, college English teachers not only need to have very high information resource extraction and integration ability, classroom organization and coordination ability, and also need to have a good network information technology application ability. Reflected in the concrete teaching practice, college English teachers should actively comply with the trend of education reform and development, "Internet +" active learning information technology and mobile Internet technology, actively carry out information-based teaching exploration and design, continue to expand and enrich the content of the education teaching with new idea, promote the informationization teaching ability and level, meet the personalized needs of students' learning, improve the learning efficiency.

\section{Developing path of teacher professional development under "internet +" era}

(1) To update teaching ideas, change the teaching idea, acquire more diverse and convenient of new knowledge and information channel

In "Internet +" era students can use computers and mobile devices anytime and anywhere to complete the learning task, the classroom is just one of the ways to acquire knowledge, teachers are no longer the only source of knowledge. "Internet + class" background, the teaching form is no longer "teachers teach and students learn", autonomous learning, active learning, cooperative learning, individualized learning. college English students learn in the main way based on the network resources and modern information technology, collaborative learning, tasks, projects and other new type of "teaching" and "learning" method, formed the new normal teaching mode with 
teachers the guider and inspirer, students actively participating in the activities. With the advent of the era of "Internet +", all kinds of teaching mode such as the micro class, flipping classroom, mobile learning platform have booming up. College English teachers should be adhering to the teaching design in preference to the concept of knowledge, actively change roles as guiders, helper and promoter of the students to learn.

(2) Update the knowledge structure and improve the information literacy

In the era of "Internet +", in order to meet the demand of students' knowledge of diversification and personalized, college English teachers have to constantly enrich their own knowledge reserves and optimize the structure of knowledge, not only should master English knowledge within the subject system, but also has a wide range of interdisciplinary knowledge related to this subject, and be able to put these knowledge into classroom teaching. Only have rich knowledge, college English teachers to whole, can make college English classroom teaching lively and interesting, let the students have more harvest, demonstrated the value of teachers' knowledge to reassure. With the continuous development of Internet and information technology, college English teachers need to have access, analysis, integration and the ability to use information and data, using the modern information technology to replace repeated labor and timely grasp of precise and advanced, valuable information and data, so that the high quality teaching and scientific research task.

(3) The innovative teaching mode, change the teaching methods

Internet provides teachers and students with extremely rich resources of teaching and learning, in the face of so many complicated network and information resources, many students don't know how to choose. Therefore, college English teachers should help students to identify and select appropriate information resources, and provide the related resources to students before the class, such as network curriculum resources, the related knowledge about micro video, teaching courseware, etc. on the basis of students' autonomous learning teachers focus to disabuse again. "Internet +" broke the traditional teaching mode of the development of the boundaries of time and space, create a teaching environment of digitalization, normalization and intelligent and based on the "We Chat + mobile network" multiple interactive learning environment. Build diverse network ecological environment, college English teaching is to arouse students' interest in learning English, also helps to further improve the college English teaching effect and teaching quality.

(4) To optimize the teaching design and teaching evaluation

In order to take the initiative to comply with the "Internet + " development trend of education reform, college English teachers should take the initiative to learn the information technology and mobile Internet technology, actively carry out information-based teaching exploration and design, continue to expand and enrich the content of the education teaching with new idea, promote the informationization teaching ability and level, meet the personalized needs of students' learning, improve the students' learning efficiency. Future in the era of big data will help college English teachers' teaching evaluation way of make up only by the performance evaluation of a piece of paper. By using the mobile Internet terminals, college English teachers to students of resource utilization, the degree of interaction in the learning activities, classroom to answer the question situation, answering questions, such as job submission situation accurately collect and quantization, as students' learning achievement evaluation factors, formation evaluation., the deficiency of students learning can be found as soon as possible, also can improve the level of learning, to overcome the traditional exam results alone and make the disadvantages of summative evaluation Through these data and the results of the analysis. Based on the network platform and big data tracking evaluation provides a new perspective for the teaching evaluation way, to a large extent can optimize the college English teachers' teaching design and teaching evaluation process.

\section{Summary}

In current college English teaching reality, the teacher level exists many problems such as teaching ideas and old ideas, knowledge structure didn't suit the practical demand for social development, old teaching skills and methods, and lack of teachers' professional development and etc. The new education idea in "Internet +" era has brought great opportunities and challenges for the 
development of college English teachers' professional ability, so college English teachers should initiatively adapt to the needs of higher education and the social sustainable development, actively update teaching concept and change teaching conception, renew the knowledge structure and improve the data and information literacy, improve teaching pattern and change teaching methods, optimize teaching design and teaching evaluation, realize the sustainable development of college English teachers. Teachers can improve the teaching effect and teaching quality of college English, and promote a new round of teaching reform and development of foreign language education by creating intelligent teaching management and service system, building the sustainable development incentive mechanism and development mechanism for college English teachers' professional, actively promoting the college English curriculum and teachers team construction.

\section{References}

[1] R. Bi. The challenges and countermeasures for the university teachers' professional ability under the background of "Internet + class" [J]. Modern education management, 2015 (12) : 50 to 55.

[2] Y. H. Chen. The connotation discussion of the sustainable development of university teachers under the new situation [J]. Journal of Jinan university (social science edition), 2012 (03) : 87-90.

[3] A.W. Jia. Policy research about American foreign language teaching education and professional qualifications standard [J]. Foreign language world, 2006 (2) : 41 and 46.

[4] A. F. Luo, Z. H. Zhang. Investigation and study of college foreign language teachers' professional development situation [J]. Foreign language world, 2007 (4) : 51 and 55.

[5] Z. Yang. Scientific research present situation and problem analysis of college English teachers [J]. Foreign language teaching, 2001 (22).

[6]J. Y. Huang. Improving teachers' accomplishment and activating the innovation consciousness [J]. Foreign language teaching research, 2005 (3). 